\title{
Intermittent hypercalcaemia and vitamin D sensitivity in Hodgkin's disease
}

\author{
R. Karmali, S. Barker, M. Hewison, L. Fraher, D.R. Katz and J.L.H. \\ O'Riordan
}

Departments of Medicine and Pathology, Middlesex Hospital, London WIN 8AA, UK.

\begin{abstract}
Summary: A patient with Hodgkin's disease spontaneously developed steroid-responsive hypercalcaemia during two consecutive summers. Administration of $3000 \mathrm{U} /$ day of vitamin $D$, while he was normocalcaemic, caused a sharp increase in serum $1,25(\mathrm{OH})_{2} \mathrm{D}_{3}$ (from $59 \mathrm{pg} / \mathrm{ml}$ to $142 \mathrm{pg} / \mathrm{ml}$ ) and subsequently hypercalcaemia while serum $25(\mathrm{OH}) \mathrm{D}_{3}$ rose moderately within the normal range (from $2.8 \mathrm{ng} / \mathrm{ml}$ to $10 \mathrm{ng} / \mathrm{ml}$ ). During a spontaneous episode of hypercalcaemia which was accompanied by increased circulating $1,25(\mathrm{OH})_{2} \mathrm{D}_{3}$ concentrations, administration of hydrocortisone decreased serum $1,25(\mathrm{OH})_{2} \mathrm{D}_{3}$ rapidly (from $115 \mathrm{pg} / \mathrm{ml}$ to $62 \mathrm{pg} / \mathrm{ml}$ ) and eventually led to normocalcaemia while serum 25(OH)D $\mathrm{D}_{3}$ remained unchanged. Thus the disturbances of mineral metabolism found in this patient with Hodgkin's disease are very similar to those previously described in sarcoidosis.
\end{abstract}

\section{Introduction}

Hypercalcaemia with increased circulating concentrations of 1,25 dihydroxycholecalciferol $\left(1,25(\mathrm{OH})_{2} \mathrm{D}_{3}\right)$ has been well established in sarcoidosis $^{1,2}$ and has been also reported in other situations involving granulomatous processes such as in disseminated candidiasis, ${ }^{3}$ silicone-induced granulomata, ${ }^{4}$ tuberculosis, ${ }^{5}$ plasma cell granuloma ${ }^{6}$ and leprosy. ${ }^{7}$ Recently it has been suggested that the same biochemical combination of hypercalcaemia, with suppressed parathyroid function and inappropriate circulating concentrations of $1,25(\mathrm{OH}){ }_{2} \mathrm{D}_{3}$ can occur in patients with Hodgkin's ${ }^{8-12}$ or non-Hodgkin's lymphoma. ${ }^{8,13,14}$ Here we describe a patient with Hodgkin's disease in whom calcium and vitamin $\mathrm{D}$ metabolism behaved in a similar manner to that associated with sarcoidosis ${ }^{15}$ with a typical response to steroid therapy and to a vitamin $\mathrm{D}$ challenge test.

\section{Methods}

Serum calcium, corrected for serum albumin, phosphate, creatinine, urea and alkaline phosphatase were measured by automated methods. Serum parathyroid hormone (iPTH) was measured in an amino-terminal immunoradiometric assay. ${ }^{16}$ Vitamin D metabolites were measured as described previously. ${ }^{17}$

Correspondence: R. Karmali, M.D., Department of Medicine, Middlesex Hospital, Mortimer Street, London W1N 8AA.

Accepted: 20 April 1990

\section{Case report and results}

A 70 year old patient was referred to us following episodes of symptomatic hypercalcaemia (up to $3.9 \mathrm{mmol} / \mathrm{l}$ ) which occurred during two consecutive summers. The raised calcium was corrected on each occasion by prednisolone which was given only for a few weeks. He came to us shortly after the second hypercalcaemic episode and was still on steroids. His past medical history was unremarkable and he denied ingestion of drugs such as vitamin D, vitamin A or thiazides. Physical examination showed mild anaemia only. Results of blood and urine investigations at admission to this hospital are shown in Table I. In addition he had a low haemoglobin $(9.8 \mathrm{~g} / \mathrm{dl})$ with normal red cell indices. Chest X-ray skeletal survey and bone scan were both normal. Computed tomographic scan of the abdomen showed only minimal enlargement of the spleen. Prednisolone was stopped and 6 weeks later a Kveim test was performed and was found to be negative. Since there was no obvious explanation for the intermittent character of the hypercalcaemia, he underwent a vitamin $D$ challenge test during which he was given $3000 \mathrm{U}$ of cholecalciferol (vitamin $D_{3}$ ) per day. At the beginning, he was normocalcaemic $(2.32 \mathrm{mmol} / \mathrm{l})$ and normocalciuric ( $4.2 \mathrm{mmol} / 24$ hours) with a creatinine clearance of $54 \mathrm{ml} / \mathrm{min}$. Serum concentrations of $25(\mathrm{OH}) \mathrm{D}_{3}$ and $1,25(\mathrm{OH})_{2} \mathrm{D}_{3}$ were normal being $2.8 \mathrm{ng} / \mathrm{ml}$ and $59 \mathrm{pg} / \mathrm{ml}$ respectively. As shown in Figure 1 , serum $25(\mathrm{OH}) \mathrm{D}_{3}$ rose gradually within the normal range up to $10 \mathrm{ng} / \mathrm{ml}$. In contrast, serum $1,25(\mathrm{OH})_{2} \mathrm{D}_{3}$ showed a dramatic and sharp increase reaching 
Table I Blood and urine measurements at admission

\begin{tabular}{lcc}
\hline & $\begin{array}{c}\text { Patient } \\
\text { values }\end{array}$ & $\begin{array}{c}\text { Normal } \\
\text { range }\end{array}$ \\
\hline Blood & & \\
Calcium & $2.31 \mathrm{mmol} / 1$ & $2.25-2.55$ \\
Phosphate & $1.01 \mathrm{mmol} / 1$ & $0.60-1.50$ \\
Alkaline phosphatases & $242 \mathrm{IU} / 1$ & $100-280$ \\
Urea & $6.2 \mathrm{mmol} / 1$ & $3.0-7.0$ \\
Creatinine & $101 \mu \mathrm{mol} / 1$ & $45-110$ \\
iPTH & $<40 \mathrm{pg} / \mathrm{ml}$ & $<120$ \\
$25(\mathrm{OH}) \mathrm{D}_{3}$ & $11.0 \mathrm{ng} / \mathrm{ml}$ & $3-40$ \\
& $(28 \mathrm{nmol} / \mathrm{l})$ & $(8-102)$ \\
$1,25(\mathrm{OH})_{2} \mathrm{D}_{3}$ & $65 \mathrm{pg} / \mathrm{ml}$ & $20-65$ \\
& $(156 \mathrm{pmol} / \mathrm{l})$ & $(48-156)$ \\
Protein electrophoresis & $\mathrm{normal}$ & $16-50$ \\
Angiotensin converting & $30 \mathrm{IU} / 1$ & $16-50$ \\
enzyme & & \\
Urine & & \\
Calcium & $3.1 \mathrm{mmol} /$ & $2.5-7.5$ \\
Creatinine clearance & $55 \mathrm{ml} / \mathrm{min}$ & \\
\end{tabular}

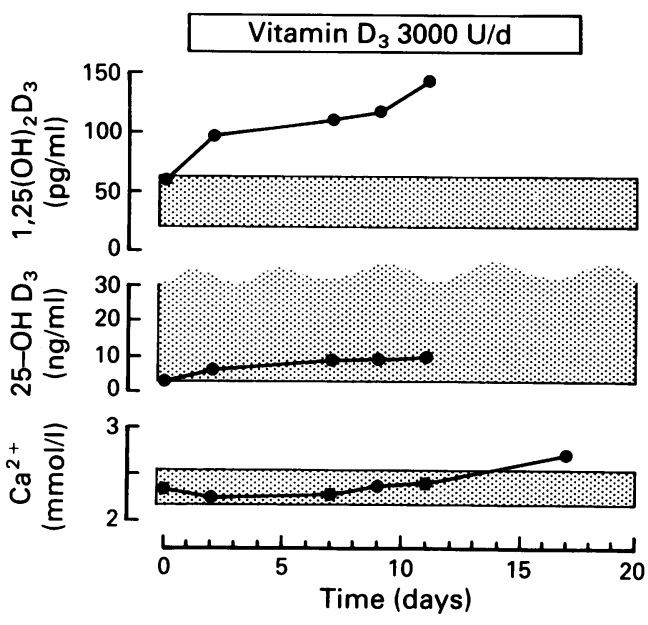

Figure 1 Effect of vitamin $D_{3}(3000 \mathrm{U} /$ day $)$ on circulating $1.25(\mathrm{OH})_{2} \mathrm{D}_{3}$ (top panel, $25(\mathrm{OH}) \mathrm{D}_{3}$ (middle panel) and serum calcium (bottom panel). Hatched areas represent the normal range.

$145 \mathrm{pg} / \mathrm{ml}$ on the 11 th day. Hypercalcaemia $(2.79$ $\mathrm{mmol} / \mathrm{l}$ ) developed on the 17 th day and was accompanied by hypercalciuria (11.9 mmol/24 hours) and a fall in creatinine clearance $(39 \mathrm{ml} /$ min). Serum iPTH remained undetectable throughout the test. After stopping the vitamin $\mathrm{D}_{3}$ supplements, serum calcium decreased gradually and the patient became almost normocalcaemic $(2.58 \mathrm{mmol} / \mathrm{l}) 15$ days later. During the vitamin $\mathrm{D}$ challenge test, there was a strong positive correlation between circulating $25(\mathrm{OH}) \mathrm{D}_{3}$ and $1,25(\mathrm{OH})_{2} \mathrm{D}_{3}(r=0.93 ; P<0.05)$.
However, no overt cause could be found for the anaemia and this led to a bone marrow examination which showed that it was infiltrated by lymphoid aggregates with some large eosinophil cells. Typical binucleated Reed-Sternberg cells were present. The histological picture was compatible with that of Hodgkin's disease. He kept well without any treatment until the following summer when he spontaneously developed hypercalcaemia $(2.99 \mathrm{mmol} / \mathrm{l})$ and hypercalciuria $(16.2 \mathrm{mmol} / 24$ hours) accompanied by a deterioration in creatinine clearance $(44 \mathrm{ml} / \mathrm{min})$. Serum concentrations of $25(\mathrm{OH}) \mathrm{D}_{3}$ and $1,25(\mathrm{OH})_{2} \mathrm{D}_{3}$ were $9.8 \mathrm{ng} / \mathrm{ml}$ and $115 \mathrm{pg} / \mathrm{ml}$ respectively. He was given hydrocortisone $(120 \mathrm{mg} /$ day $)$ and Figure 2 illustrates the evolution of serum calcium and vitamin $D_{3}$ metabolites with this treatment. On the 4th day, the $1,25(\mathrm{OH})_{2} \mathrm{D}_{3}$ had fallen within the normal range $(62 \mathrm{pg} / \mathrm{ml})$ while the $25(\mathrm{OH}) \mathrm{D}_{3}$ was unchanged $(9.1 \mathrm{ng} \mathrm{ml})$. On the 10th day, he was normocalcaemic, urinary calcium had decreased to 10.6 $\mathrm{mmol} / 24$ hours and creatinine clearance had improved to $65 \mathrm{ml} / \mathrm{min}$. He was then maintained on prednisolone $(30 \mathrm{mg} / \mathrm{d})$ and no further episodes of hypercalcaemia occurred. However, 8 months later, an abdominal CT scan showed that the spleen had enlarged markedly and in addition, retroperitoneal lymphadenopathy could be seen. The patient underwent splenectomy and histology was pathognomonic of Hodgkin's disease; no granulomas were present. Lymph nodes showed complete replacement of the normal tissue by a tumour infiltrate resembling that found in the spleen and again no granulomas were seen. Thus these findings confirmed the diagnosis of Hodgkin's disease. Two months later, almost 4 years after the initial presentation, the patient died after a severe respiratory infection. No post-mortem examination was performed.

\section{Discussion}

The histological diagnosis in this patient was that of Hodgkin's disease; neither sarcoidosis nor any other granulomatous disease previously associated with hypercalcaemia and increased circulating concentrations of $1,25(\mathrm{OH})_{2} \mathrm{D}_{3}$ could be demonstrated. However, the disturbances of calcium homeostasis reported here are similar to those described in sarcoidosis. There was a seasonal pattern of the spontaneous hypercalcaemic episodes which occurred during the summer months and moreover there was a close association between hypercalcaemia and the abnormally raised circulating concentration of $1,25(\mathrm{OH})_{2} \mathrm{D}_{3}{ }^{15}$ in the absence of vitamin D intoxication. This relationship was reproduced and documented by vitamin D challenge. When small supplements of cholecalci- 


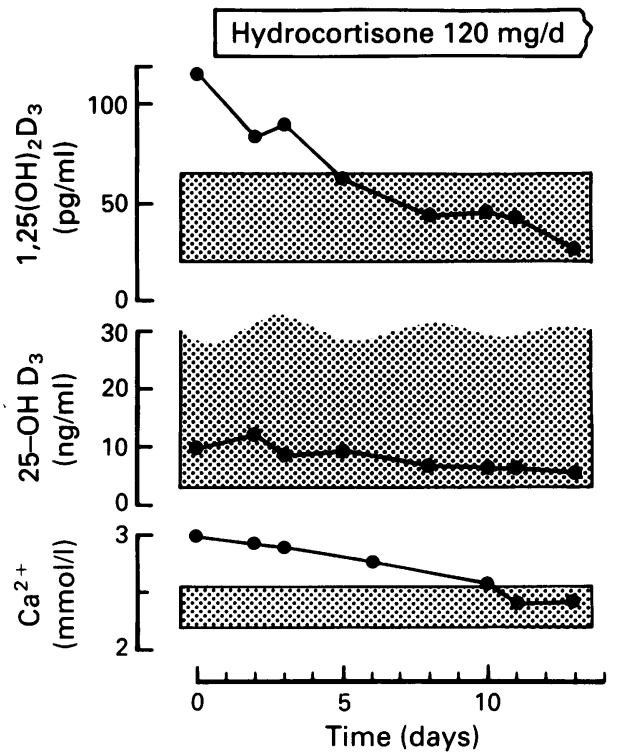

Figure 2 Changes induced by hydrocortisone $(120 \mathrm{mg} /$ day) in circulating $1,25(\mathrm{OH})_{2} \mathrm{D}_{3}$ (top panel), $25(\mathrm{OH}) \mathrm{D}_{3}$ (middle panel) and serum calcium (bottom panel). Normal range is represented by the hatched areas.

ferol were given, in order to mimic the spontaneous situation occurring in summer, serum $25(\mathrm{OH}) \mathrm{D}_{3}$ increased moderately within the normal range but the $1,25(\mathrm{OH})_{2} \mathrm{D}_{3}$ showed an abrupt rise well over the normal concentrations, preceding by a few days the development of hypercalcaemia. As in sarcoidosis, ${ }^{15}$ in this patient, there was also an abnormal positive substrate-product relationship between circulating concentrations of $25(\mathrm{OH}) \mathrm{D}_{3}$ and 1,25 $(\mathrm{OH})_{2} \mathrm{D}_{3}$ and in addition the abnormal $1 \alpha$-hydroxylase activity was responsive to steroids which corrected not only the abnormal vitamin D meta- bolism but also disturbances in calcium homeostasis.

The origin of the abnormal $1 \alpha$-hydroxylase activity in patients with lymphoma in whom hypercalcaemia is associated with increased serum 1,25 $(\mathrm{OH})_{2} \mathrm{D}_{3}$ is still not clear but there are arguments suggesting an extra-renal origin to the enzyme. High circulating concentrations of $1,25(\mathrm{OH})_{2} \mathrm{D}_{3}$ have been found in patients with lymphoma and severe renal failure. ${ }^{8,13}$ In addition, normalization of the circulating concentrations of $1,25(\mathrm{OH})_{2} \mathrm{D}_{3}$ and resolution of hypercalcaemia after treatment of the lymphoma have also been reported. ${ }^{8,10,12,13}$ The substrate-product relationship between circulating $25(\mathrm{OH}) \mathrm{D}_{3}$ and $1,25(\mathrm{OH})_{2} \mathrm{D}_{3}$ and the steroid sensitivity of the $1 \alpha$-hydroxylase activity also support the ectopic origin of the enzyme. However, it is not obvious whether this abnormal $1 \alpha$-hydroxylase activity is confined to the tumoral tissue or stems from other tissue known to normally possess the enzyme, ${ }^{18}$ stimulated by humoral factors secreted by the neoplastic cells. Some observations would favour the location of the abnormal synthesis of $1,25(\mathrm{OH})_{2} \mathrm{D}_{3}$ to the lymphomatous tissue itself, since in vitro production of the active metabolite of vitamin $\mathrm{D}_{3}$ was demonstrated in a lymph node homogenate from a patient with lymphoma ${ }^{14}$ and also in T lymphocytes transformed with the HTLV I virus, ${ }^{19}$ a virus strongly associated with the adult T-cell lymphoma.

It is, however, not yet clear whether $1,25(\mathrm{OH})_{2} \mathrm{D}_{3}$ is solely responsible for the abnormal mineral metabolism in this condition or acts in concert with other factors known to be associated with hypercalcaemia in malignant disease. ${ }^{20}$

\section{Acknowledgement}

We wish to thank the Medical Research Council for financial support.

\section{References}

1. Papapoulos, S.E., Clemens, T.L., Fraher, L.J., Lewin, I.G., Sandler, I.M. \& O'Riordan, J.L.H. 1,25-dihydroxycholecalciferol in the pathogenesis of the hypercalcaemia of sarcoidosis. Lancet 1979, i: 627-630.

2. Bell, N.H., Stern, P.H., Pantzer, E., Sinha, T.K. \& DeLuca, H.F. Evidence that increased circulating $1 \alpha-25$-hydroxyvitamin $D$ is the probable cause for abnormal calcium metabolism in sarcoidosis. J Clin Invest 1979, 64: 218-225.

3. Kantarjian, H.M., Saad, M.F., Estay, E.H., Sellin, R.V. \& Samaan, N.A. Hypercalcaemia in disseminated candidiasis. Am J Med 1983, 74: 721-724.

4. Kozeny, G.A., Barbato, A.L., Bansal, V.R., Vertino, L.L. \& Hano, J.E. Hypercalcaemia associated with silicone-induced granulomas. N Engl J Med 1984, 311: 1103-1105.

5. Gnokos, P.J., London, R. \& Hendler, E.D. Hypercalcaemia and elevated 1,25-dihydroxyvitamin $D$ levels in a patient with end-stage renal disease and active tuberculosis. $N$ Engl J Med 1984, 311: 1683-1685.

6. Helikson, M.A., Harvey, A.D., Zerweckh, J.E., Breslau, N.A. \& Gardner, D.G. Plasma cell granuloma producing calcitriol and hypercalcaemia. Ann Intern Med 1986, 105: 379-381.

7. Hoffman, V.N. \& Korzeniowski, O.M. Leprosy, hypercalcaemia and elevated serum calcitriol levels. Ann Intern Med 1986, 105: 890-891.

8. Rosenthal, N., Insogna, K.L., Godsall, J.W., Smaldone, L., Waldron, J.A. \& Stewart, A.F. Elevation in circulating 1,25-dihydroxyvitamin $D$ in three patients with lymphomaassociated hypercalcaemia. J Clin Endocrinol Metab 1985, 60: 29-33.

9. Zaloga, G.P., Eil, C. \& Medbery, C.A. Humoral hypercalcaemia in Hodgkin's disease. Association with elevated 1,25-dihydroxycholecalciferol levels and subperiostal bone resorption. Arch Int Med 1985, 145: 155-157.

10. Davies, M., Mawer, E.B., Hayes, M.E. \& Lumb, G.A. Abnormal vitamin D metabolism in Hodgkin's lymphoma. Lancet 1985, i: 1186-1188. 
11. Schaefer, K., Saupe, J., Pauls, A \& von Herrath, D. Hypercalcaemia and elevated serum 1,25-dihydroxyvitamin $D_{3}$ in a patient with Hodgkin's lymphoma. Klin Wochenschr 1986, 64: 89-91.

12. Mercier, R.J., Thompson, J.M., Harman, G.S. \& Messerchmidt, G.L. Recurrent hypercalcaemia and elevated 1,25dihydroxyvitamin D levels in Hodgkin's disease. Am J Med 1988, 84: 165- 168.

13. Breslau, N.A., McGuire, J.L., Zerweckh, J.E., Frenkel, E.P. \& Pack, C.Y.C. Hypercalcaemia associated with increased serum calcitriol levels in three patients with lymphoma. Ann Intern Med 1984, 100: 1-7.

14. Mudde, A.H., van den Berg, H., Boshuis, P.G. et al. Ectopic production of 1,25-dihydroxyvitamin D by B-cell lymphoma as a cause of hypercalcemia. Cancer 1987, 59: 1543-1546.

15. Sandler, I.M., Winearls, C.G., Fraher, L.J., Clemens, T.L., Smith, R. \& O'Riordan, J.L.H. Studies of the hypercalcaemia of sarcoidosis: effects of steroids and exogenous vitamin $D_{3}$ on the circulating concentrations of 1,25-dihydroxyvitamin $\mathrm{D}_{3} . Q J \mathrm{Med}$ 1984, 210: 165-180.

16. Papapoulos, S.E., Manning, R.M., Hendy, G.N., Lewin, I.G. \& O'Riordan, J.L.H. Studies of circulating parathyroid hormone in man using a homologous amino terminal specific immunoradiometric assay. Clin Endocrinol 1983, 13: 57-67.
17. Fraher, L.J., Adami, S., Clemens, T.L., Jones, G. \& O'Riordan, J.L.H. Radioimmunoassay of 1,25-dihydroxy vitamin $D_{2}$ : studies on the metabolism of vitamin $D_{2}$ in man. Clin Endocrinol 1983, 18: 151-165.

18. Mason, R.S. Extra-renal production of $1,25(\mathrm{OH})_{2} \mathrm{D}_{3}$ : the metabolism of vitamin $D$ by non traditional tissues. In: Norman, A.W., Schaefer, K., Grigoleit, H.-G. \& Herrath, D.V. (eds) Vitamin D: Chemical, Biochemical and Clinical Update. Walter DeGruyter, Berlin, 1985, pp. 23-32.

19. Fetchick, D.A., Bertolini, D.R., Sarin, P.S., Weintraub, S.T., Mundy, G.R. \& Dunn, J.F. Production of 1,25-dihydroxyvitamin $D_{3}$ by human $T$ cell lymphotropic virus-I-transformed lymphocytes. J Clin Invest 1986, 78: 592-596.

20. Motokura, T., Fukumoto, S., Takahashi, S. et al. Expression of parathyroid hormone-related protein in a human $\mathrm{T}$ cell lymphotrophic virus type I-infected cell line. Biochem Biophys Res Commun 1988, 154: 1182-1188. 